\title{
PENGARUH AMPLITUDE SONIC BLOOM SINGLE TONE TERHADAP PERKECAMBAHAN BENIH TOMAT CHERRY (Lycopersicum cerasiforme Mill.) SEBAGAI DESAIN SUMBER BELAJAR BIOLOGI
}

\author{
Netri Murni ${ }^{1}$ \\ Achyani $^{2}$ \\ Handoko Santoso ${ }^{3}$ \\ ${ }^{1}$ SMK Negeri 1 Baradatu, Way Kanan \\ ${ }^{2,3}$ Magister Pendidikan Biologi UM Metro \\ Email: arnetri@gmail.com
}

\begin{abstract}
Sound exposure to seed germination is an attempt to increase germination, growth in stem length and sprout width. This study aims to determine the effect of amplitude (Sound Level) on the germination of cherry tomato seeds, to know the best amplitude Single Tone for the efficiency of germination of cherry tomato seeds and to compile the results of research as a source of learning on growth and growth material in plants in the form of Student WorkSheets. The research design using Completely Randomized Design, with 5 treatments and 4 replications. The treatment is Single Tone amplitude / volume (decibel / dB) variation consisting of PO (without sound), P1 (65 dB), P2 (75 dB), P3 (85 dB) and P4 $(95 \mathrm{~dB})$. The results showed that the amplitude Single Tone significantly affected the growth of stem length and leaf width $(P>0,05)$. The best treatment is $P 3$ with amplitude $85 \mathrm{~dB}$ which produces average germination rate, the growth of stem length and leaf width of $99 \%, 5.84 \mathrm{~cm}$ and $0.29 \mathrm{~cm}$, respectively, whereas the lowest treatment on without sound (P0) $91 \%$ for germination, and $0.23 \mathrm{~cm}$ for leaf width. As well as on P4 (95 dB) of $4.90 \mathrm{~cm}$ for the length of cherry tomato sprout stems. Research results can be developed as learning resources in the form of Student WorkSheets.
\end{abstract}

Keywords: Amplitude (dB) Cherry Tomato Seed, Germination, Single Tone.

Tomat cherry dianggap sebagai varietas botani dari jenis Solanum Lycopersicum yang berasal dari daerah subtropik, tetapi kini penanamannya bisa di negara tropik seperti Indonesia. Tomat cherry banyak diminati karena mengandung vitamin $\mathrm{C}$ lebih tinggi daripada buah jeruk serta rasa yang lebih manis dan segar dari tomat biasa, bentuk dan ukurannya unik dengan berat ratarata hanya 25-30 gram/buah dan diameter 2-3 cm/buah. Oleh karena itu tomat cherry lebih banyak digunakan untuk salad, olahan sayur, sambal terasi atau dikonsumsi sebagai buah segar (Wahyudi, 2012).

Keunggulan tomat cherry dari tomat yang lain adalah toleran untuk dibudidayakan di dataran menengah sampai rendah, bahkan dipinggir pantai sekalipun tomat cherry mampu berbuah lebih awal. Perawatannya tergolong sangat mudah. Untuk menghasilkan tomat cherry yang baik diperlukan bibit tomat cherry yang berkualitas, dalam perawatannya cukup air dan diletakkan ditempat yang teduh cukup sinar matahari untuk 
memperkuat batang pada saat awal pertumbuhannya, yakni pada saat perkecambahannya.

Dalam kurun dua dasawarsa terakhir ini dikenal teknologi Sonic Bloom yang mampu mempengaruhi perkecambahan dan pertumbuhan tanaman, serta meningkatkan kuantitas dan kualitas hasil pertanian. Sonic bloom merupakan teknologi yang memanfaatkan efek gelombang suara (frekuensi dan amplitude) untuk meningkatkan pertumbuhan tanaman yang diciptakan oleh Dan Carlson dari Amerika Serikat dan mulai disebarkan secara komersial pada tahun 1980. Sonic Bloom berfungsi memacu membukanya mulut daun (stomata) yang dipadu dengan pemberian nutrisi (Mulyadi dkk, 2005). Suara yang menghasilkan getaran bunyi tersebut dapat mempengaruhi pembukaan stomata daun menjadi lebih besar (Kadarisman dkk, 2011). Sehingga dapat menyerap air dan $\mathrm{CO}_{2}$ lebih banyak dan mengoptimalkan proses fotosintesis, akibatnya pertumbuhan dan produktivitas tanaman dapat ditingkatkan secara optimal.

Teknologi gelombang suara juga telah terbukti mampu meningkatkan kecepatan perkecambahan, terbukti penggunaan teknologi sonic bloom dapat menyuburkan pertumbuhan semai dan mempercepat pertumbuhan pada tanaman (Yulianto, 2008).

Weinberg \& Measures (1979) melakukan penelitian pada pertumbuhan perkecambahan biji gandum menggunakan teknologi gelombang suara berfrekuensi 5000 $\mathrm{Hz}$ dengan Sound Pressure Level (SPL) 92 dB. Biji gandum ketika diberi perlakuan gelombang suara dapat merangsang pertumbuhan perkecambahan biji, tinggi batang dan jumlah akar. Penelitian juga dilakukan Prasetyo (2014) dimana level suara musik klasik 70-75 dB selama 3 jam setiap hari dimulai pukul 07.00-10.00, 70-75 dB dapat meningkatkan daya berkecambah biji sawi hijau sebesar 15\%, tinggi tanaman sebesar $13,5 \%$, lebar daun sebesar $14,8 \%$, panjang daun sebesar $14,2 \%$ dan berat basah sebesar $57,1 \%$.

Wuryani dkk (2014), Menyatakan bahwa kualitas hasil tomat cherry dengan penggunaan Sonic Bloom pada gelombang suara frekuensi 3500-5000 Hertz pada waktu antara pukul 07.00-10.00 jumlah stomata yang membuka nyata lebih banyak hingga 100\%. Efek gelombang suara pada benih padi menunjukkan bahwa pertumbuhan perkecambahan biji, tinggi batang, aktivitas sistem akar dan penetrasi dari membran sel secara signifikan meningkat pada frekuensi suara 400 $\mathrm{Hz}$ dan SPL $106 \mathrm{~dB}$ (Wang dkk, 2003).

Menurut (Mareza et al, 2009 dalam Prasetyo, 2014 : 19) bahwa pemaparan suara dapat merangsang aktifitas enzim pada kotiledon benih sehingga berkecambah lebih cepat, selain itu dugaan lain mengindikasikan terjadi peningkatan vigor benih yang dapat 
meningkatkan daya berkecambah suatu tanaman

Dari penelitian tersebut terbukti bahwa Sonic Bloom dapat diaplikasikan pada semua jenis tanaman mulai dari tanaman semusim misalkan padi, palawija, bunga-bungaan hingga tanaman tahunan seperti kopi, kakao, karet, kelapa sawit, jati, meranti, dsb.

Inti dari Sonic Bloom adalah gelombang suara yang merupakan nada, yaitu gabungan berbagai sinyal getar terdiri dari gelombang harmonis dengan kecepatan getar osilasi atau frekuensi yang diukur dalam satuan getaran Hertz $(\mathrm{Hz})$ dan amplitude atau kenyaringan bunyi dengan pengukuran dalam satuan tekanan suara decibel (dB).

Berdasarkan penelitian yang telah dilakukan oleh peneliti sebelumnya diduga pemanfaatan Sonic Bloom (gelombang suara) merupakan salah satu cara untuk meningkatkan percepatan perkecambahan benih. Untuk meningkatkan daya berkecambah benih tomat cherry selain pengaruh air, suhu dan kelembaban serta cahaya matahari maka diperlukan treatment khusus yaitu pemaparan suara single tone pada frekuensi tertentu dengan variasi amplitude pada tingkat perkecambahan sebagai awal pertumbuhan tomat cherry. Single tone dalam penelitian ini merupakan nada tunggal yang memiliki kecepatan getar atau frekuensi $(\mathrm{Hz})$ dan amplitude atau kenyaringan bunyi (dB) yang dapat terukur.
Pengaruh gelombang suara pada perkecambahan benih tomat cherry belum diteliti sebelumnya. Hal ini yang menjadi pemicu rasa ingin tahu peneliti untuk mengetahui pengaruh frekuensi dan amplitude terhadap perkecambahan benih tomat cherry dan mengetahui ampitude yang efektif untuk daya berkecambah benih tomat cherry. Benih varietas tomat cherry dalam penelitian ini memiliki beberapa keunggulan dibandingkan dengan benih tomat cherry varietas lainnya, yaitu: adaptable di dataran rendah dan sedang, tingkat keseragaman tinggi, strees tolerance tinggi, ketahanan penyakit tinggi, umur panen relatife cepat (70-75 HST), potensi hasil tinggi (40-60 ton/ha).

Pada penelitian ini peneliti menggunakan dan merealisasikan sebuah audio aplikasi perangkat lunak komputer (software) Tone Generator yang menghasilkan gelombang suara dengan frekuensi suara $(\mathrm{Hz})$ dan Sound Pressure Level $(d B)$ single tone yang dapat diukur menggunakan Sound Level Meter yang bisa diubah-ubah (Variable). Sedangkan penentuan frekuensi dan variasi amplitude di dasarkan pada penelitian sebelumnya yang dilakukan oleh Hageseth di awal tahun 1973 dan Prasetyo (2014).

Perangkat audio ini akan diintegrasikan pada chamber (kotak isolasi cerdas) yang diadopsi dari penelitian (Prasetyo, 2014) dengan sedikit modifikasi, yakni terbuat dari stereoform ukuran $(53 \times 38 \times 34) \mathrm{cm}$ dan menggunakan plastik transparan 
sebagai penutupnya. Chamber berfungsi sebagai peredam suara, agar benih tomat cherry hanya fokus

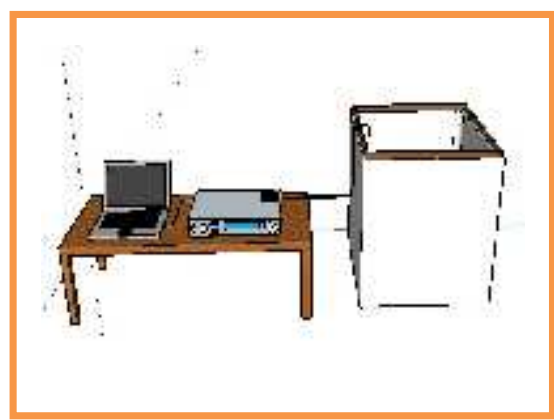

Gambar 1. Rangkaian Chamber Dilihat Dari Depan

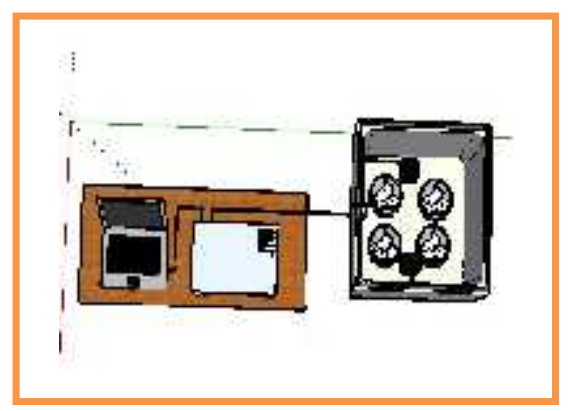

Gambar 3. Rangkaian Chamber Dilihat Dari Atas

Sumber belajar berupa Lembar Kegiatan Peserta Didik (LKPD) yang akan dikembangkan dalam penelitian ini merupakan salah satu sarana untuk membantu dan mempermudah dalam kegiatan belajar mengajar sehingga penggunaan LKPD pada materi pertumbuhan dan perkembangan pada tumbuhan ini diharapkan akan terbentuk interaksi (feedback) yang efektif antara peserta didik dengan pendidik serta antar sesama peserta didik untuk membangun pemahaman konsep, pengembangan diri serta keterampilan dan kompetensi peserta didik. pada treatment suara saja. Rangkaian chamber terdiri atas: laptop, speaker aktif dan chamber.

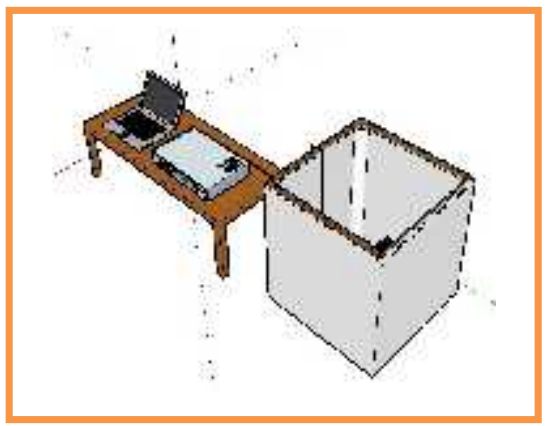

Gambar 2. Rangkaian Chamber Dilihat Dari Samping

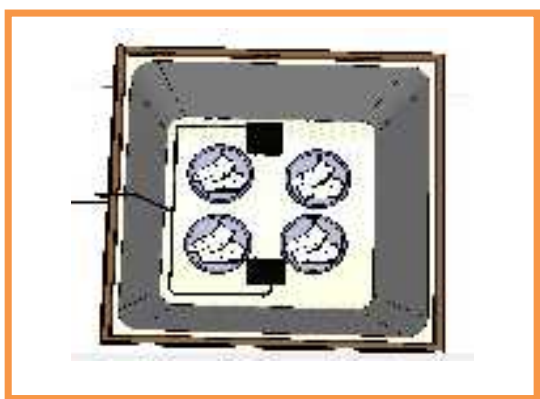

Gambar 4. Benih Tomat Cherry Dalam Chamber

Berdasarkan latar belakang di atas, maka penelitian ini bertujuan untuk:

1. Mengetahui pengaruh amplitude (Level Suara) single tone terhadap perkecambahan benih tomat cherry.

2. Mengetahui amplitude single tone yang terbaik untuk efisiensi perkecambahan benih tomat cherry.

3. Menyusun hasil penelitian sebagai sumber belajar pada materi pertumbuhan dan perkembangan pada tumbuhan dalam bentuk Lembar Kegiatan Peserta Didik (LKPD). 


\section{METODE}

Penelitian ini telah dilaksanakan pada tanggal 6 Juli 2017 sampai 12 Juli 2017 di Greenhouse SMKN 1 Baradatu Way Kanan. Penelitian dilakukan secara eksperimen menggunakan Rancangan Acak Lengkap (RAL) dengan 5 perlakuan dan 4 kali ulangan. Perlakuan dibedakan berdasarkan variasi amplitude/level suara $(\mathrm{dB})$ single tone yang dipaparkan, dengan perlakuan yang diberikan adalah sebagai berikut:

P0 : tanpa pemberian suara (kontrol)

$\mathrm{P} 1$ : pemaparan suara $65 \mathrm{~dB}$

P2 : pemaparan suara $75 \mathrm{~dB}$

P3 : pemaparan suara $85 \mathrm{~dB}$

P4 : pemaparan suara $95 \mathrm{~dB}$

Objek penelitian yang

digunakan adalah benih tomat cherry (Lycopersicum cerasiforme Mill.) yang diproduksi oleh PT. Aditya Sentana Agro, Kabupaten Malang.

Penelitian dilaksanakan pada tahap awal perkecambahan benih tomat cherry yang dipelihara selama 7 hari, pengukuran dilakukan dua kali yaitu tahap mulai berkecambah (hari ke-4) dan akhir pemeliharaan (hari ke-7), yang meliputi daya berkecambah, pertumbuhan panjang batang dan lebar daun kecambah. Pengambilan sampel dilakukan dengan cara mengambil sampel secara acak setiap cawan petri perlakuan sebanyak 5 benih tomat cherry untuk pengukuran panjang batang dan lebar daunnya. Daya berkecambah dihitung jumlah benih yang berkecambah dalam setiap cawan petri perlakuan.
Persentase benih yang berkecambah dihitung dengan rumus:

$$
\mathbf{T}=\mathbf{b} / \mathbf{t} \times 100 \%
$$

Keterangan :

$\mathrm{T}=$ Persentase benih yang berkecambah

$\mathrm{b}=$ Jumlah benih yang berkecambah $\mathrm{t}=$ Total benih yang disebar

Data hasil penghitungan benih yang berkecambah yang diperoleh dianalisis dengan menggunakan Uji Non-Parametrik Kruskall Wallis.

Data hasil pengukuran panjang batang kecambah yang diperoleh dianalisis dengan menggunakan Analisis Varian (ANOVA) untuk menentukan perlakuan berbeda atau tidak. Jika hasilnya berbeda nyata $(\mathrm{P}<0,05)$ atau berbeda sangat nyata $(\mathrm{P}<0,01)$ maka dilanjutkan Uji Lanjut Multiple Comparison Scheffe untuk mengetahui perbedaan antar perlakuan.

Data hasil lebar daun kecambah yang diperoleh tidak terdistribusi normal, selanjutnya dianalisis dengan Uji NonParametrik Kruskal Wallis.

\section{HASIL}

Data hasil pengukuran ratarata perkecambahan benih tomat cherry dari setiap perlakuan tersaji pada gambar di bawah ini: 


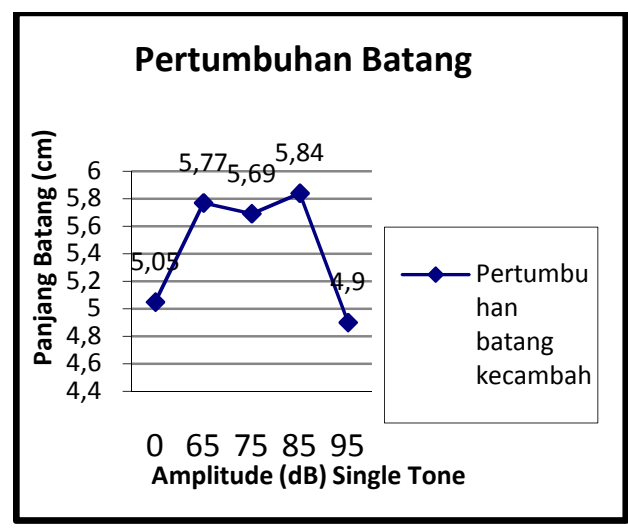

Gambar 5. Grafik Daya Berkecambah Tomat Cherry

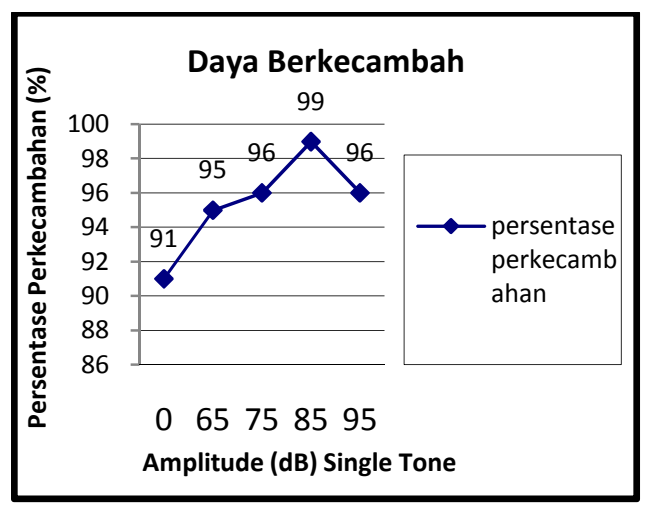

Gambar 6. Grafik Pertumbuhan Panjang Cherry

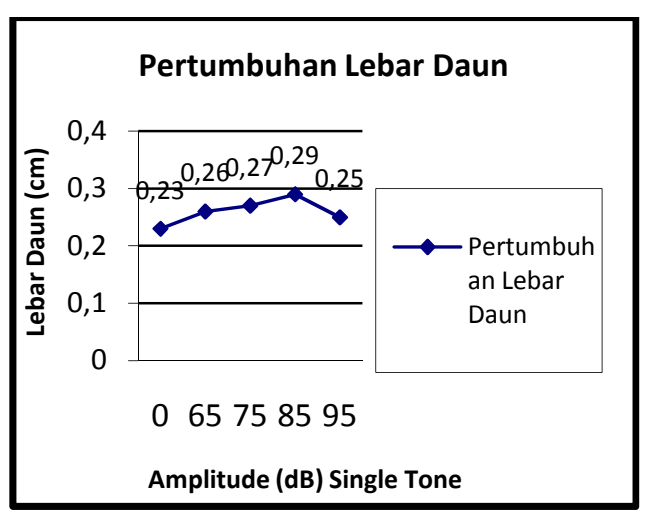

Gambar 7. Grafik Pertumbuhan Lebar Daun Kecambah Tomat Cherry

Tabel 1. Ringkasan Hasil Uji Hipotesis Non-Parametri Kruskal Wallis pada Perkecambahan Tomat Cherry Selama Penelitian

\begin{tabular}{clcccc}
\hline \multirow{2}{*}{ No } & Variabel Uji & \multicolumn{2}{c}{ Hasil Pengujian } & Simpulan & $\begin{array}{c}\text { Perlakuan } \\
\text { Terbaik }\end{array}$ \\
\cline { 3 - 4 } & $\begin{array}{c}\text { Chi- } \\
\text { Square }\end{array}$ & Sig. & & P3 \\
\hline 1 & $\begin{array}{l}\text { Jumlah benih yang } \\
\text { berkecambah }\end{array}$ & 5,402 & 0,248 & $\begin{array}{c}\text { Tidak ada } \\
\text { pengaruh }\end{array}$ & $\begin{array}{c}\text { Ada penga } \\
\text { ruh }\end{array}$ \\
\hline $\begin{array}{l}\text { Pertumbuhan lebar } \\
\text { daun kecambah }\end{array}$ & 19,918 & 0,001 & P3 \\
\hline
\end{tabular}

Tabel 2. Ringkasan Hasil Uji Hipotesis Anova Satu Arah pada Perkecambahan Tomat Cherry Selama Penelitian

\begin{tabular}{|c|c|c|c|c|c|c|}
\hline \multirow{2}{*}{ No } & \multirow{2}{*}{ Variabel Uji } & \multicolumn{2}{|c|}{ Hasil Pengujian } & \multirow{2}{*}{$\begin{array}{c}\text { F tabel } \\
(4,95)(0,05)\end{array}$} & \multirow{2}{*}{$\begin{array}{l}\text { Sim- } \\
\text { pulan }\end{array}$} & \multirow{2}{*}{$\begin{array}{c}\text { Perla } \\
\text { kuan } \\
\text { Ter } \\
\text { baik } \\
\end{array}$} \\
\hline & & F hitung & Sig. & & & \\
\hline 1. & $\begin{array}{l}\text { Pertumbuhan } \\
\text { panjang batang } \\
\text { kecambah }\end{array}$ & 11,117 & 0,000 & 2,46 & $\begin{array}{l}\text { Ada } \\
\text { Penga } \\
\text { ruh }\end{array}$ & P3 \\
\hline
\end{tabular}




\section{PEMBAHASAN}

Hasil penelitian (Tabel 1) menunjukkan pada Chi-Square $(5,402)$ Asymp. Sig $=0,248>\alpha=$ 0,05 yang berarti pemberian variasi decibel $(\mathrm{dB})$ tidak berpengaruh nyata terhadap perkecambahan benih tomat cherry.

Hasil penelitian rata-rata daya berkecambah, yaitu sebesar P0 (91\%), P1 (95\%), P2 (96\%),P3 (99\%) dan P4 (96\%). Daya berkecambah optimal yakni pada P3 (99\%) dan terendah pada P0 (91\%). Secara statistik variasi decibel yang diberikan tidak berpengaruh terhadap daya berkecambah, namun jika dilihat dari data menunjukkan bahwa suara single tone dapat mempengaruhi daya berkecambah tomat cherry. Hal ini dapat terjadi karena pemaparan suara dapat merangsang aktifitas enzim pada kotiledon benih sehingga berkecambah lebih cepat (Mareza et al (2009) dalam Prasetyo, 2014). selain itu dugaan lain mengindikasikan terjadi peningkatan vigor benih yang dapat meningkatkan daya berkecambah.

Hasil penelitian pertumbuhan batang menunjukkan $F$ hitung $(11,117)>\mathrm{F}$ tabel $(2,46)$ yang berarti pemberian variasi amplitude $(\mathrm{dB})$ berpengaruh nyata terhadap pertumbuhan panjang batang kecambah tomat cherry. Pengujian lanjut Multiple Comparison dengan Uji Scheffe menunjukkan bahwa terdapat perbedaan pengaruh variasi amplitude (dB) terhadap pertumbuhan panjang batang kecambah antar perlakuan.

Pada pertumbuhan panjang batang kecambah tomat cherry hasil rata-rata pada $\mathrm{P} 0(5,05 \mathrm{~cm}), \mathrm{P} 1(5,77$ $\mathrm{cm}), \mathrm{P} 2(5,69 \mathrm{~cm}), \mathrm{P} 3(5,84 \mathrm{~cm})$ dan P4 $(4,90 \mathrm{~cm})$. Hal ini menunjukkan bahwa variasi decibel secara signifikan mempengaruhi pertumbuhan panjang batang kecambah tomat cherry. dan pertumbuhan optimal terdapat pada P3 $(5,84 \mathrm{~cm})$ yakni pada level suara $85 \mathrm{~dB}$, sedangkan pertumbuhan terendah pada P4 $(4,90 \mathrm{~cm})$ yakni pada level suara $95 \mathrm{~dB}$.

Rerata nilai pertumbuhan panjang batang kecambah tomat cherry pada pemaparan suara single tone dengan amplitude $(\mathrm{dB})$ yang bervariasi menunjukkan hasil yang lebih baik dibandingkan dengan tanpa pemaparan suara single tone. Pada perlakuan P1 yakni suara single tone sebesar $65 \mathrm{~dB}$ sudah dapat meningkatkan pertumbuhan panjang batang kecambah dibandingkan dengan P0 ( tanpa perlakuan). Pada perlakuan P1,P2 dan P3 dengan variasi decibel single tone, laju pertumbuhan panjang batang kecambah semakin meningkat selama pemeliharaan, sejalan dengan pertambahan decibel.

Pada Chi-square $(19,918)$ Asymp Sig $=0,001<\alpha=0,05$, dengan Uji Non-Parametrik Kruskal Wallis menunjukkan bahwa pemberian variasi decibel $(\mathrm{dB})$ berpengaruh nyata terhadap pertumbuhan lebar daun tomat cherry. Secara signifikan variasi 
decibel mempengaruhi pertumbuhan lebar daun kecambah tomat cherry. Pertumbuhan optimal terdapat pada P3 $(0,29 \mathrm{~cm})$ yang lebih besar dari $\mathrm{P} 0(0,23 \mathrm{~cm}), \mathrm{P} 1(0,26 \mathrm{~cm}), \mathrm{P} 2(0,27$ $\mathrm{cm})$, dan P4( $0,25 \mathrm{~cm})$. Pertumbuhan lebar daun terendah terdapat pada P0 $(0,23 \mathrm{~cm})$.

Hal ini menunjukkan bahwa energi atau getaran yang dihasilkan oleh sumber suara tersebut mempunyai efek terhadap suatu tanaman, yaitu mampu merangsang stomata daun untuk membuka. Getaran dari suara akan memindahkan energi ke permukaan daun dan akan menstimulasi stomata daun untuk membuka lebih lebar. Dengan membukanya stomata lebih lebar berarti penyerapan unsur hara dan bahan-bahan lain di daun menjadi lebih banyak jika dibandingkan dengan tanaman tanpa perlakuan suara. Terbukti pada hasil penelitian ini bahwa pemaparan suara dengan variasi amplitude $(\mathrm{dB})$ single tone mampu meningkatkan pertumbuhan lebar daun dibandingkan dengan tanpa pemaparan suara (tanpa perlakuan).

Hasil penelitian secara keseluruhan menunjukkan perlakuan terbaik dengan nilai tertinggi terdapat pada perlakuan $\mathrm{P} 3(85 \mathrm{~dB})$ masingmasing sebesar 99\% untuk persentase daya berkecambah, 5,84 $\mathrm{cm}$ untuk panjang batang kecambah dan $0,29 \mathrm{~cm}$ untuk lebar daun. Sedangkan perlakuan dengan nilai terendah terdapat pada P0 sebesar 91\% untuk persentase daya berkecambah, pada P0 yakni sebesar
$0,23 \mathrm{~cm}$ untuk lebar daun, dan untuk panjang batang kecambah pada $\mathrm{P} 4$ $(95 \mathrm{~dB})$ sebesar $4,90 \mathrm{~cm}$.

Hal ini berarti semakin tinggi level suara $(\mathrm{dB})$ single tone yang diberikan pada benih memberikan hasil pertumbuhan yang lebih baik, dan sampai pada pertumbuhan optimum akan mengalami penurunan pertumbuhan kembali. Pada P3 dengan level suara sebesar $85 \mathrm{~dB}$ menghasilkan pertumbuhan kecambah yang lebih optimal.

Hal ini menunjukkan bahwa untuk perkecambahan yang optimal bagi tomat cherry membutuhkan amplitude /level suara single tone sebesar $85 \mathrm{~dB}$. Setiap jenis tanaman mampu tumbuh dengan optimal pada level suara (amplitude) tertentu, sebagaimana penelitian yang dilakukan Weinberg \& Measures (1979), pada pertumbuhan perkecambahan biji gandum menggunakan teknologi gelombang suara berfrekuensi $5000 \mathrm{~Hz}$ dengan Sound Pressure Level (SPL) 92 dB.

$$
\text { Daya berkecambah }
$$

dipengaruhi oleh aktivitas sel dan enzim pada kotiledon dan pertumbuhan kecambah dipengaruhi oleh pembukaan stomata dan aktifitas pembelahan sel pada fase pasca berkecambah. Suara dengan frekuensi tertentu bisa mempengaruhi pembukaan stomata (Van Doorne, 2000).

Menurut Carlson (2001), serapan nutrisi daun dan serapan air dapat ditingkatkan karena sifat permeabilitas membran stomata. Beberapa suara dengan frekuensi 
tertentu beresonansi sehingga meningkatkan gerakan sitoplasma di dalam sel. Sehingga mampu meningkatkan pertumbuhan dan pertambahan sel tumbuhan yang berdampak pada daya berkecambah, pertambahan panjang batang dan lebar daun. Selain itu sumber suara dengan frekuensi tertentu dapat mengaktifkan gen tertentu dalam sel, sehingga mempengaruhi pertumbuhan dan ekspresi sel (Sternheimer, 1993).

Dari hasil penelitian membuktikan bahwa secara umum paparan suara single tone memberikan hasil terbaik terhadap karakteristik morfologi kecambah tomat cherry.

Faktor eksternal diduga ikut mempengaruhi perkecambahan pada penelitian ini. Hasil pengukuran faktor pendukung perkecambahan bahwa besaran- besaran nya masih dalam batas kelayakan dan mendukung perkecambahan tomat cherry. Perbandingan hasil pengukuran faktor pendukung perkecambahan yang meliputi suhu, $\mathrm{pH}$, dan kelembaban dengan kisaran normal untuk pemeliharaan perkecambahan benih tomat cherry dapat dilihat pada Tabel 3.

Tabel 3. Data Faktor Pendukung Perkecambahan Tomat Cherry Selama Penelitian

\begin{tabular}{|c|c|c|c|c|c|c|}
\hline \multirow{2}{*}{ Variabel } & \multicolumn{5}{|c|}{ Perlakuan } & \multirow{2}{*}{$\begin{array}{l}\text { Kisaran } \\
\text { Normal }\end{array}$} \\
\hline & P0 & P1 & P2 & P3 & $\mathrm{P} 4$ & \\
\hline Suhu $\left({ }^{\circ} \mathrm{C}\right)$ & $24-27$ & $24-27$ & $24-27$ & $24-27$ & $24-27$ & $21-35^{\mathrm{a}}$ \\
\hline $\mathrm{pH}$ & 6 & 6 & 6 & 6 & 6 & $5-7^{\mathrm{b}}$ \\
\hline Kelembaban $(\%)$ & $73-85$ & $73-85$ & $73-85$ & $73-85$ & $73-85$ & $50-85^{c}$ \\
\hline
\end{tabular}

Keterangan: Yamaguchi, $1983^{\text {a }}$; Agromedia, 2007 ${ }^{\mathrm{b}}$ Harjadi, 1995

Suhu udara selama pemeliharaan berada pada kisaran 24$27^{\circ} \mathrm{C}$. Hal ini sesuai yang dikemukakan Yamaguchi (1983 293), bahwa suhu ideal yang baik untuk perkecambahan tomat cherry berkisar antara $21-35^{\circ} \mathrm{C}$. Apabila suhu pemeliharaan melebihi kisaran akan menghambat perkecambahan tomat cherry. Sebaliknya jika suhu pemeliharaan kurang dari kisaran (suhu rendah) mengakibatkan benih akan gagal untuk berkecambah atau terjadi kerusakan yang mengakibatkan terbentuknya kecambah abnormal.
Berdasarkan

hasil pengukuran $\mathrm{pH}$ air didapatkan $\mathrm{pH} 6$. Bila $\mathrm{pH}$ lebih rendah dari 4,0 pada umumnya terjadi kenaikan $\mathrm{Al}^{3+}$ yang berdampak secara fisik merusak sistem perakaran terutama akar muda sehingga menghambat perkecambahan dan pertumbuhan benih. Selain itu $\mathrm{pH}$ rendah juga dapat meyebabkan klorosis dan memungkinkan terjadinya hambatan terhadap pertumbuhan mikroorganisme yang bermanfaat bagi mineralisasi unsur hara seperti $\mathrm{N}$ dan $\mathrm{P}$ dan mikroorganisme yang berpengaruh pada pertumbuhan 
tanaman, misalnya bakteri tanah yang dapat bersimbiosis dengan leguminosa seperti Rhizobium atau bersimbiosis dengan tanaman non leguminosa seperti Frankia sehingga sering dijumpai daun-daun tanaman pada tanah asam mengalami klorosis akibat kekurangan $\mathrm{N}$.

Kelembaban udara perlakuan juga masih dalam batas yang normal yaitu $50-85 \%$. Nilai kisaran ini masih layak mendukung perkecambahan tomat cherry. Sebagaimana diungkapkan dalam Harjadi (1995 ; 105), bahwa benih tomat cherry dapat berkecambah pada kelembaban tepat di atas titik layu permanen, yaitu kisaran $50-85 \%$. Hal ini berhubungan dengan ketersediaan air yang mendukung dalam proses perkecambahan.

Berdasarkan hasil analisis potensi sumber belajar bahwa hasil penelitian ini dapat dikembangkan menjadi sumber belajar biologi SMK dalam bentuk Lembar Kegiatan Peserta Didik pada materi Pertumbuhan dan Perkembangan pada Tumbuhan (Faktor Luar yang Mempengaruhi Pertumbuhan dan Perkembangan pada Tumbuhan). LKPD divalidasi oleh tiga orang validator terdiri atas 2 orang dosen dan satu orang guru SMK, meliputi aspek kelayakan isi, kegrafikan, dan kebahasaan. Berdasarkan hasil validasi, LKPD yang telah disusun dinyatakan "sangat baik" dan layak untuk digunakan dalam proses pembelajaran.

\section{KESIMPULAN}

1. Perlakuan variasi amplitude suara single tone $(65 \mathrm{~dB}, 75 \mathrm{~dB}, 85 \mathrm{~dB}$ dan $95 \mathrm{~dB}$ ) tidak berpengaruh secara signifikan terhadap daya berkecambah benih tomat cherry (Chi-Square $=5,402$ nilai Asymp. Sig $=0,248>\alpha=0,05$ ). Dilihat dari data perlakuan variasi amplitude (dB) yang terbaik untuk daya berkecambah tomat cherry (Lycopersicum cerasiforme Mill.) terdapat pada perlakuan P3 (99 \%) dan terendah P0 (91\%).

2. Perlakuan variasi amplitude $(\mathrm{dB})$ suara single tone memberikan pengaruh secara signifikan terhadap pertumbuhan panjang batang kecambah (F hitung 11,117 > F tabel 2,46). Perlakuan variasi amplitude $(\mathrm{dB})$ single tone yang terbaik untuk pertumbuhan panjang batang kecambah tomat cherry (Lycopersicum cerasiforme Mill.) terdapat pada perlakuan P3 $(5,84$ $\mathrm{cm})$ dan terendah $\mathrm{P} 4(4,90 \mathrm{~cm})$.

3. Pertumbuhan lebar daun kecambah dengan Uji NonParametrik Kruskal Wallis (Chisquare $(19,918)$ Asymp Sig $=0,001$ $<\alpha=0,05) \quad$ Perlakuan variasi amplitude $(\mathrm{dB})$ suara single tone memberikan pengaruh secara signifikan terhadap pertumbuhan lebar daun kecambah tomat cherry (Lycopersicum cerasiforme Mill.). Perlakuan variasi amplitude $(\mathrm{dB})$ single tone yang terbaik untuk pertumbuhan lebar daun 
kecambah tomat cherry (Lycopersicum cerasiforme Mill.) terdapat pada perlakuan P3 $(0,29$ $\mathrm{cm})$ dan terendah P0 $(0,23 \mathrm{~cm})$.

4. Hasil penelitian dapat dikembangkan sebagai sumber belajar pada materi pertumbuhan dan perkembangan pada tumbuhan dalam bentuk LKPD.

\section{SARAN}

Berdasarkan kesimpulan yang diperoleh, diajukan beberapa saran sebagai berikut:

1. Gelombang suara (Sonic Bloom) sangat baik dan efektif untuk menstimulasi perkecambahan dalam upaya peningkatan kualitas benih atau untuk perkecambahan benih dan penyiapan bibit siap tanam dengan harapan dapat mempercepat laju perkecambahan.

2. Gelombang suara dapat menjadi alternatif dalam meningkatkan perkecambahan benih tomat cherry dan memperpendek waktu penyiapan bibit siap tanam dengan frekuensi dan amplitude single tone tertentu.

3. Model ini secara biofisik dapat dikembangkan dan diaplikasikan dalam produk pertanian.

4. Perlu diadakan penelitian lebih lanjut mengenai pengaruh suara single tone dengan variasi amplitude (dB) yang sama atau berbeda, namun terhadap pertumbuhan buah tomat cherry.
DAFTAR RUJUKAN

Asrul. 2015. Pemasangan Perangkat MP3-Player sebagai Sumber Suara pada Penerapan Teknologi Sonic Bloom. Tesis Program Pasca Sarjana Teknik Komputer, Kendali dan Elektronika. Makasar: UnHas Makasar.

Carlson, D. 2001. Black Engineer, Summer Sound Nutrition, "Will Music Eliminate World Hunger?", Secrets of the Soil, by Peter Tompkins and Christopher Bird, Harper \& Row.

Van Doorne Y. 2000. Thesis : Influence of variable sound frequencies on the growth and developpement of plants. Hogeschool Gent. Belgium. 22 June.

Harjadi, S. S. 1995. Dasar-Dasar Hortikultur. Bogor : Jurusan Budidaya Pertanian Fakultas Pertanian Institut Pertanian Bogor.

Kadarisman N, Purwanto A., Rosana D. 2011. Rancang Bangun audio growth system melalui Spesifikasi Spektrum Bunyi Binatang Alamiah sebagai local genius untuk Peningkatan Kualitas dan Produktivitas Tanaman Holtikultura. Prosiding. Seminar Nasional Penelitian, Pendidikan, dan Penerapan MIPA: Universitas Negeri Yogyakarta, Yogyakarta.

Mulyadi A.T., P. Mairani dan A. Sunandar. 2005. Pengaruh 
Teknologi Pemupukan

Bersama Gelombang Suara

(Sonic Bloom) Terhadap

Perkecambahan dan

Pertumbuhan Semai acacia mangium Willd. Jurnal

Manajemen Hutan Tropika

Vol. XI No $1: 67-75$.

Prasetyo, J. 2014. Efek Paparan

Musik dan Noise pada

Karakteristik Morfologi dan

Produktivitas Tanaman Sawi

Hijau (Brassica juncea).

Jurnal Keteknikan Pertanian

Vol 2, No. 1

Sternheimer J. 1993. Lecture:

Epigenetic regulation of protein biosynthesis by scale resonance. Kanagawa Science Academy and Teikyo Hospital

(Tokyo). May 20.

Wahyudi, 2012. Bertanam Tomat di Dalam Pot dan Kebun Mini. Cianjur : Agromedia Pustaka.

Wuryani, S., H. Herastuti, D. Supriyanto. 2014. Respon Kualitas Hasil Tomat Cherry (Lycopersicum cerasiforme
Mill.) terhadap Penggunaan

Teknologi Sonic Bloom dengan Berbagai Pupuk Daun. Jurnal Agrivet $18: 1-5$

Yamaguchi, M. 1983. World Vegetables. Avi Publishing Company, Inc. California. Yulianto. 2008. Pengkajian dan Pengembangan Teknologi Gelombang Suara dan Nutrisi Rumput Laut pada Cabai Merah (Capsicum annuum L.). Jurnal Agroland 15(1): 16.

Weinberge P, \& Measures M, 1979. Effects of the intensity of audible sound on the growth and development of Rideau winter wheat. Canadian Journal of Botany, 57, 10361039.

Wang B. C., Chen X., Wang Z., Fu Q Z, Zhou H, Ran L. 2003. Biological effect of sound field stimulation on paddy rice seed . Colloids, 32, 29-34. and Surfaces (B: Biointerfaces) 